\title{
Model of Motor Skills to Improve Life Skill of Elementary School Children in Palembang, Indonesia
}

\author{
Rudy Noor Muktamar ${ }^{1}$, Tandiyo Rahayu ${ }^{2}$, HariAmirullah Rachman ${ }^{3}$, Setya Rahayu ${ }^{4}$ \\ ${ }^{1}$ Department of Youth and Sports of South Sumatra Province, Indonesia \\ 1,2,3,4 Department of Sports Education, Graduate School, UNNES, Indonesia \\ ${ }^{1}$ Corresponding author: rudynoormuktamar@gmail.com
}

\begin{abstract}
Development of human resources from an early age becomes an important requirement. The emergence of various problems in society shows that knowledge and life skills become a major part of society. The purpose of this research is to get information about the influence of psychomotor skills model on the development of life skills of elementary school children in Palembang city. This research procedure uses development research. The research product is BALS motor skills model (Active Learning Life Skills). Small-scale trials were conducted in two elementary schools, SDN 135 Palembang and SDN 106 Palembang. Large-scale trials were conducted at the Islamic Elementary School AzZahrah Palembang, SD Xaverius 2 Palembang \& SD IBA Palembang. The total subjects involved were 340 students. Motor skills data were obtained by measuring the motor skills of students using Test of Gross Motor Development (TGMD). Implementation of BALS motor skills model showed an increase in the average life skill score of students. Before the implementation, the score was 24.96 and after learning. The score becomes 28.29 . The percentage of life skill learning outcomes of elementary school students on a large scale shows $8.0 \%$ excellent category, $78.6 \%$ good, $11.2 \%$ less, and $2.2 \%$ least. The result of life skills of students with affective assessment shows the influence of BALS motor skills model on the development of life skills of elementary school students. This research produces instruction manual for teaching BALS motor skills model. The existence of product manuals can provide input to other development model research, to make the learning of the motor skills of elementary school students more creative and interesting.
\end{abstract}

Keywords: Model Development, Motor Skills, Life Skills, Elementary School Students

\section{Introduction}

Education is expected to accommodate and prepare students for their attitudes, skills, and knowledge for the future. The main objectives of physical education are to provide students with knowledge, skills, abilities, behaviors, and confidence, to be physically active throughout their lives (Sallis et al., 2012). Physical education as an integral part of education will help students undergo optimal growth and development processes both physical, motor, mental and social (Rukmana, 2008). The subject of physical education in elementary school is a learning tool for measured and structured children's movement, in the context of learning as a whole.

According to Clersida \& Garcia, 2006, the development of children's motor becomes one of the tasks of physical education teachers through learning activities in school. Students are expected to have the practical experience and knowledge necessary to achieve successful motion. This is so that there are no gap issues during adulthood, environmental adaptation, and duties that will be implemented in the future.
Life skills are abilities for the adaptive and positive behavior of everyday life (WHO, 2003). Children and adolescents are very important to be introduced to the personal development, cognitive development, and development of life skills, which will depend on each other (Yuen, 2011). The relevance of physical education as a human movement is movement education which is seen as a very appropriate learning approach as it relates to physical education as a life skill (Rukmana, 2008).

According to (Nicholas et al., 2009), participants studying social life skills can interact with peers in the context of sports activities. Parents use sports to reinforce the values associated with sportspersonship and work ethic. Counselors emphasize hard work and teamwork, but also prevent some negative influences on participant participation.

Based on the results of a preliminary study conducted by using questionnaires, observations and interviews, the KKG (Teachers Working Group) of physical education teachers (Penjas) in elementary school Sako sub-district Palembang, found the 
following problems: (1) $40 \%$ of primary schools do not have any suggestion for infrastructure support to learn physical education of sports and health (PJOK), (2) Variation and development of motor skills learning materials is still inadequate, (3) $65 \%$ of physical education teachers do not have the ability to develop and modify learning materials, especially motor skills.

One of the problems of supporting facilities for teaching the physical teacher, such as manual of specific motor skills model to develop life skill of child, does not yet exist. This is quite difficult for the teacher in implementing the objectives of fun and creative learning. According to Goudas (2008), a life skills program in physical education learning will result in the more effective result when the learning approach to sports is done in a team. Therefore, it is necessary to research motor skills model to develop life skills of elementary school students of Palembang city.

The study aims to develop and test whether there is an influence of the motor skills model taught by the teachers in the second and third grade of elementary school in the city of Palembang. The benefit is to facilitate teachers in the process of creative and fun learning and teaching of motor skills. The research produced product instruction manuals teaching motor skills model BALS (Active Learning Life Skills) for elementary school students.

\section{Methods}

The research procedure used in this research is the development research, while the development research steps are: 1) Preparation of manual product model of motor skills of BALS (Active Learning Life Skills), based on life skill aspect and motor skills aspect, (2) Expert validation was carried out prior to the implementation of small-scale trial, ie with Focus Group Discussion (FGD) pointed to preparing and improving BALS, (3) Trial of product conducted in SD which have implemented the 2013 curriculum. The trial was done twice, in SD NEGERI 135 (62 students) and SD NEGERI 106 (67 students) with total 129 students. Large-scale test in Islamic elementary school AzZahrah (45 students), Xaverius 2 Elementary School (72 students), IBA Elementary School (57 students), total 174 students. The overall research subjects were 303 students of grade II and III public and private elementary school in Palembang city.

Expert validation in FGD Phase I, through a demand analysis questionnaire, was carried out to assess model requirements and prepare manuals on motor skills models, before the trial phase. Indicators of the questionnaire, namely: (1) content substance (in accordance with the characteristics of learning physical education sports and health students); and (2) implementation (ease, safety, clarity, practicality, achievement of purpose and usefulness).

A total of five teachers and experts skillfully validate the model of motor skills, in the form of suggestions and assessments of the models that have been designed. Below is a model of motor skills model, which is used in a limited-scale trial and broad, namely:

Table 1: BALS Motor Skill Model Products

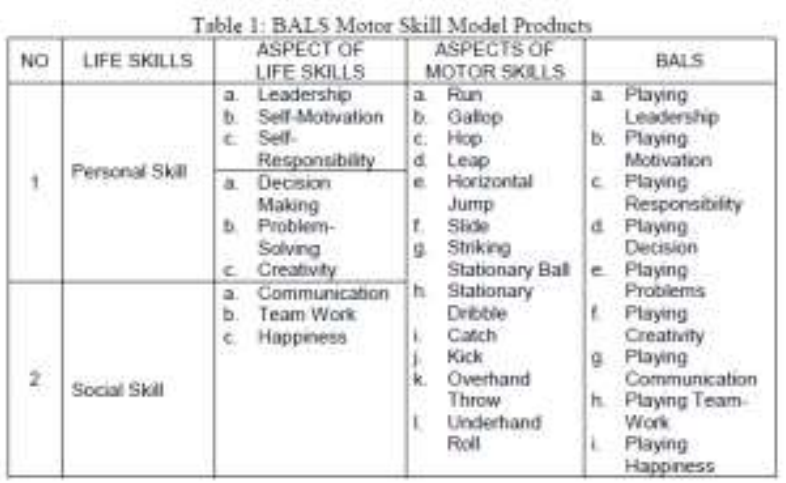

The shape of the motor skills model in Table 1, is a motion game of motor skills, which is taught to grade II and III elementary school students by a physical teacher. Motor movement activities become a means of playing with the aim of developing life skills of elementary school students.

The result of the limited scale test of the model of motor skills reveals suggestion from the teacher. The product was refined based on the suggestion. The data of large-scale test result is analyzed by using the t-test to see whether there is an influence of motor skill model on the development of life skill before and after the experiment.

\section{Results \& Discussion}

Survey result of physical teachers' need for BALS motor skill development is as follows: 
Table 2. Need Analysis of Motor Skill Model

\begin{tabular}{|l|c|c|c|c|c|c|c|c|c|c|c|}
\hline Aspect & 1 & 2 & 3 & 4 & 5 & 6 & 7 & 8 & 9 & 10 & 11 \\
\hline $\begin{array}{l}\text { Mean } \\
\text { Score }\end{array}$ & 4.07 & 4.07 & 4.00 & 4.13 & 3.93 & 4.13 & 4.20 & 4.07 & 3.93 & 4.07 & 4.13 \\
\hline Criteria & Agree & Agree & Agree & Agree & Agree & Agree & Agree & Agree & Agree & Agree & Agree \\
\hline
\end{tabular}

Notes:

Aspect $1=$ the need for a physical teacher to motor skills model.

Aspect 2 = ease of implementation of motor skills model

Aspect 3 = usefulness for physical teacher

Aspect 4 = scientific studies, comparators and experiences for physical teachers.

Aspect $5=$ develop students' life skills

Aspect $6=$ assist students in developing life skills

Aspect $7=$ solution of learning problems of teaching motor skills

Aspect $8=$ implement the skill model periodically and continuously

Aspect $9=$ can be socialized to other physical teachers

Aspect $10=$ can be used in Palembang city schools and other areas

Aspect $11=$ stakeholders can provide advice and feedback on models of motor skills

From 15 data from respondents, it can be seen that the Physical teacher agreed to 11 items of motor skills model needs. This can be seen that most of the respondents agreed.

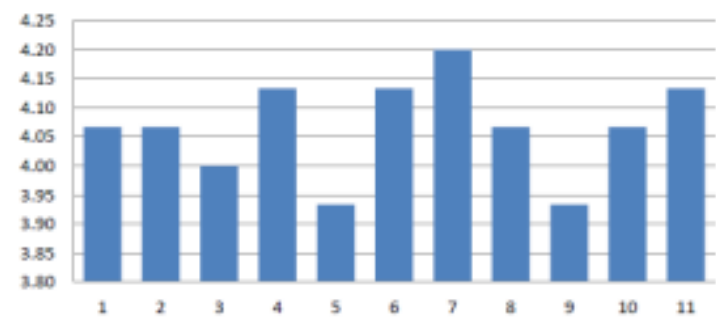

Figure 1. Score of Teacher Responses to Each Aspect (average of 15 respondents)

Data in Figure 1 showed the percentage of motor skills model needs which is up to $81.33 \%$ so that it is included in the high category. It can be concluded that primary school supervisors require the development of models of motor skills to develop life skills.

Application of motor skills model of BALS in the form of motor movement game shown in Table 1 is to develop life skills of elementary school students on learning PJOK in large-scale trials, with the number of subjects as many as 174 students. Data were taken before and after application of motor skills model. The results of the trial show that there is an increase in life skills attitude of elementary school students. Results of data processing with SPSS program is shown in Table 2 .

Table 2. T-Test of Motor Skills Data Before and After Treatment

\begin{tabular}{|l|l|l|l|}
\hline \multicolumn{1}{|c|}{ Motonic Skill } & \multicolumn{1}{|c|}{ Mean } & \multicolumn{1}{c|}{ N } & \multicolumn{1}{c|}{$\begin{array}{c}\text { Deviation } \\
\text { Standards }\end{array}$} \\
\hline Before Treatment & 24.96 & 174 & 3.100 \\
\hline After Treatment & 28.29 & 174 & 2.638 \\
\hline
\end{tabular}

Table 2 shows the mean scores of students' life skills on a wide scale before using BALS motor skills model. The mean score before treatment is 24.96 and after the treatment is 28.29. The result of t-test shows that learning motor skills using motor skills model of BALS results in higher motoric value than that of before using BALS motor skills model.

The results of trials of large-scale BALS motor skills model in the three primary schools were shown in Table 3.

Table 3: Percentage of Improvement of Life Skills Attitudes (By Using BALS)

\begin{tabular}{|c|c|c|c|c|c|c|}
\hline \multirow{2}{*}{\multicolumn{2}{|c|}{ School }} & \multicolumn{4}{|c|}{ Life SKil } & \multirow[b]{2}{*}{ Total } \\
\hline & & Very Good & Good & Less & Least & \\
\hline \multirow{2}{*}{$\begin{array}{l}\text { SD } \\
\text { Istam Az } \\
\text { Zahrah }\end{array}$} & Students & 5 & 32 & 7 & 1 & 45 \\
\hline & Percentage & 11.1 & 71.1 & 15.6 & 22 & 100 \\
\hline \multirow{2}{*}{$\begin{array}{l}\mathrm{SD} \\
\text { Xaverius } \\
2\end{array}$} & Students & 7 & 51 & 12 & 2 & 72 \\
\hline & Percentage & 97 & 70.8 & 16.7 & 28 & 100 \\
\hline
\end{tabular}

Percentage improvement in life skills attitude (Table 3) is an excellent and good category. This is because the life skill aspect is often shown by the students when undertaking to learn motor skills with BALS. It is because students have the motivation and they are happy to follow the learning activities. For the 
category of less and least, due to the life skills aspects that are rarely or never shown by the students, for example when playing a leadership and playing the responsibility, students are not familiar with learning instructions and do not get the desired partner. In addition, there is information from the physical teacher about the low level of physical fitness and body posture factors of obese (obese) students.

Table 4: T-Test of Motor Skills Model of Life Skills

\begin{tabular}{|c|c|c|c}
\hline Life SKII & \multicolumn{1}{|c|}{ Mean } & Sid. Deviation & \multicolumn{1}{c}{$\mathrm{t}$} \\
\hline Before treatment & \multirow{2}{*}{-3.328} & 2997 & -14.644 \\
\cline { 1 - 2 } After Treatment & & & \\
\hline
\end{tabular}

Based on the results of t-test on life skills data before and after implementing learning activities, it is revealed that $\mathrm{t}$ arithmetic $=$ 14.644 with a significance level of 0.05 which is smaller when it is compared with the value of $t$ table $=1.960$. This means that there is a significant difference between students' life skills before and after learning activities.

Product model of motor skills BALS in Table 1 is the result of problem investigation in the field. The results of the study were then compiled into a model of playing motor skills to develop life skills attitudes of elementary school students. BALS is in the form of the instruction manual for life skills teaching which can be used in teaching and learning process in elementary school. Every aspect of life skills consists of two models of motion play with the aim to develop life skills.

According to Rachman (2009), physical education is a sure thing for life skills education to be implemented through curriculum and learning in schools. The purpose of physical education is to synergize with life skills dimensions, both generic and specific life skills. This illustrates that life skills education can be provided through physical education in schools. Therefore, the model of motor skills used is a means and effort to develop life skills of primary school children as an experience and early recognition of life skills to the child through a model of motor skills.

The physical teacher agrees with the model of BALS motor skills to develop life skills of elementary school students. This can be seen in Table 2. The leadership of teachers is very important in the learning process. Good leadership to the child will reach the goal of learning (Darmawati et al., 2017). BALS motor skills model implemented in elementary school will depend on the role of physical education teacher. In achieving the successful development of life skills of students, the role of teachers is very large in guiding and assisting students during the learning process.

The activity of playing with tools has a greater influence than the activity of playing without tools to motor skills (Anggita \& Rachman, 2014). BALS motor skills model uses a variety of playing equipment with tools because students will be more active in following the learning activities so that more movement activities will happen to further develop the life skills of students.

According to Raudsepp and Päll (2006), the rate of development of basic motor skills will be related to the physical activity of children outside school so that with the motor skills possessed by the child, it can support the daily activities of the child in doing his duties.

Thelen (2000), stated that research on motor development contributes both the empirical and theoretical changes to human development, especially children. Preferably a physical education teacher in the primary school has a good knowledge and understanding in this regard, as it relates to the age of growth and development of elementary school children.

The benefits of this research are to be able to find useful new products as a study of literature in the field of physical education study, as well as to provide input and suggestions on education, psychology, and other related fields. The results of this study are expected to help teachers and students, in the creative and fun learning process and to provide a positive learning experience of Physical, Sports, and Health Education.

\section{Conclusion}

The research produced a product of teaching and learning manuals for teachers about motor skills models, under the name of BALS (Active Learning Life Skill). The result of BALS test shows a significant improvement of skill on the use of motor skills model to develop life skills of elementary school students class II and III in Palembang city. 


\section{References}

Anggita GM, Rachman HA. 2014. Pengaruh aktivitas bermain dan perceptual motorik terhadap keterampilan motorik siswa sekolah dasar kelas bawah. Jurnal Keolahragaan, 2 (2):170-181

Clersida G \& Garcia L. 2006. A motordevelopment And motor-learning Perspective. JOPERD. 77 (8): 68-75.

Darmawati D, Rahayu T \& Rifai RC. 2017. Leadership Guru Pendidikan Jasmani Olahraga dan Kesehatan di SMP Ogan Komering Ulu Timur Sumatera Selatan. Jurnal Physical Education and Sport. 6(2): 108 - 116

Goudas, M. 2008. A team-sport-based lifeskills program in a physical education context. Department of Physical Education and Sport Science, University of Thessaly, Greece.

Nicholas L. Holt*, Katherine AT, Lisa NT, Danielle EB.2009. An interpretive analysis of life skills associated with sport participation. Qualitative Research in Sport and Exercise.1(2): 160-175.

Rachman HA. 2009. Dimensi Kecakapan Hidup (Life Skill) Dalam Pembelajaran Pendidikan Jasmani. Jurnal Pendidikan Jasmani Indonesia. 6(2): 5-9

Rukmana A. 2008. Pembelajaran Pendidikan Jasmani di Sekolah Dasar. Jurnal Pendidikan Dasar UPI. 9(1): 21-25
Sallis, J. F., McKenzie, T. L., Beets, M. W., Beighle, A., Erwin, H., \& Lee, S. (2012). Physical Education's Role In Public Health: Steps Forward And Backward Over 20 Years And Hope For The Future. Research Quarterly for Exercise and Sport. (8)3: 125-135

Thelen E. 2000. Motor Development As Foundation And Future of Developmental Psychology. International Journal of Behavioral Development. 24 (4): 385-397.

WHO (World Health Organization). 2003. Skills for Health (Information Series on School Health Document 9)Geneva.http://www.who.int/school_ youth_health/media/en/sch_skills4heal th 03.pdf(download 3 September 2015)

Yuen M. 2011. Asian Journal of Counselling, Fostering Connectedness and Life Skills Development in Children and Youth: International Perspectives. The Hong Kong Professional Counselling Association International Perspectives on Connectedness in Children and Adolescents. The University of Hong Kong, 18 (1-2): 1-14

Raudsepp and Päll. 2006. The Relationship between Fundamental Motor Skills and Outside-School Physical Activity of Elementary School Children. Human Kinetic Journal. 18 (4): 42643. 